\title{
CARBONATITOS LINEARES DE CINTURÕES MÓVEIS : UMA SÍNTESE
}

\author{
ALEKSANDR VLADIMIROVICH LAPIN* , WOLDEMARIWANUCH** \& VITOLD VLADIMIROVICH PLOSHKO*
}

\begin{abstract}
LINEAR CARBONATITES FROM MOBILE BELTS: A REVIEW The linear carbonatites from mobile belts are located in fault zones, extend over scores of kilometers, are not directly associated with ioneous alkaline rocks, but are surrounded by wide zoned aureoles of alkaline metasomatites (fenites). They are conformable with the altitude of the host rocks, and run parallel to the overall orientation of the mobile belt; intrusion of the carbonatite bodies occurs prior to stabilization of the mobile belt and precedes the orogenic phase. The carbonatite bodies occur in current mobile belts, folded belts of Neogen, and in analogous formations from the Paleozoic and Proterozoic ages. They show comparatively simple mineral composition, single-petrographic facies, single-stage of intrusion, clear vertical differentiation, characterized by three distinct intrusion facies of carbonatites, according to the depth of emplacement in relation to the paleorelief: shallow depth facies $(2-5 \mathrm{~km}$, $\left.\mathrm{T}<400^{\circ} \mathrm{C}, \mathrm{P}<1,5 \mathrm{kbar}\right)$; middle depth $\left(5-10 \mathrm{~km}, \mathrm{~T}=400-600^{\circ}, \mathrm{P}=1,5-3,0 \mathrm{kbar}\right)$ and great depth $\left(>10 \mathrm{~km}, \mathrm{~T}>600^{\circ} \mathrm{C}, \mathrm{P}>3 \mathrm{kbar}\right)$. Each of the fácies is cohstituted by a proper assemblage of tipomorphic rock and ore forming minerais. To exemplify, we describe the general features of the two linear carbonatites most studied abroad, as well as the only one of its type known in Brazil to date.
\end{abstract}

Keywords: linear carbonatites, mobile belts, folded belts, fault zones, mineral deposits.

RESUMO Carbonatitos lineares de cinturõçs móveis alojam-se em zonas de falhas, estendem-se por dezenas de quilômetros, não têm associação com rochas alcalinas magmáticas, mas acham-se envoltos por possantes auréolas zonadas de metassomatitos alcalinos (fenitos). Apresentam disposição concordante em relação às rochas encaixantes, perlongando-se paralelamente à estruturação geral do cinturão móvel; a intrusão desses corpos é anterior à estabilização do cinturão móvel e corresponde à fase pré-orogênica. Ocorrem em cinturões atuais, faixas de dobramentos do Neógeno e em seus análogos do Paleozóico e Proterozóico. Têm uma composição mineralógica relativamente simples, com uma fácies petrográfica e um único estágio de intrusão; exibem uma notória diferenciação vertical, caracterizada por três fácies distintas de carbonatitos em função da profundidade de colocação em relação ao paleorelevo: baixa $\left(2-5 \mathrm{~km}, \mathrm{~T}<400^{\circ} \mathrm{C}, \mathrm{P}<1,5 \mathrm{kbar}\right)$; média $(5-10 \mathrm{~km}, \mathrm{~T}=$ $\left.400-600^{\circ}, \mathrm{P}=1,5-3,0 \mathrm{kbar}\right)$ e alta $\left(>10 \mathrm{~km}, \mathrm{~T}>600^{\circ} \mathrm{C}, \mathrm{P}>3 \mathrm{kbar}\right.$ ). Cada uma das fácies é representada por uma assembleia própria de minerais tipomórficos formadores de rocha e de minério. A guisa de exemplo, descrevem-se os traços mais gerais de dois dos carbonatitos lineares mais bem estudados no exterior e o único do género conhecido no Brasil até o presente.

Palavras-chave: Carbonatitos lineares, cinturões móveis, faixas de dobramento, depósitos minerais.

INTRODUÇÃO A ideia de que o magmatismo carbonatítico somente se manifestava em plataformas e em faixas de dobramentos consolidadas foi derrubada pela descoberta de carbonatitos em ambientes não-plataformais. Podemos citar como exemplos cinturões móveis, ilhas oceânicas e assoalho oceânico, sendo que os dois últimos ambientes não serão objeto de análise neste artigo. Obviamente essas descobertas revestem-se de grande importância tanto no que concerne à petrologia dos carbonatitos, como no prognóstico de jazimentos minerais que se lhes associam.

As características morfológicas dos complexos carbonatíticos expressam notória e cabalmente o regime geológico-tectônico de sua formação: ortoplataformas e cinturões móveis.

Ao examinarmos a morfologia dos complexos carbonatíticos, de imediato distinguimos dois tipos extremos: um deles é representado por complexos intrusivos do Tipo Central, os quais se caracterizam pela sua forma arredondada ou oval e com frequente distribuição anelar zonal das rochas constituintes (Fig. 1, corpos 1 a 3) e o outro é representado por Zonas Lineares de Carbonatitos e Fenitos (Fig. 1, corpos 4 a 6$)$

Os complexos do Tipo Central ocorrem em ortoplataformas tanto nas suas partes centrais como nas marginais, e neles os carbonatitos apresentam-se na forma de diques e veios anelares ou cónicos, stocks e plugs, associados a rochas ultrabásicas, ultrabásicas alcalinas, básicas alcalinas e alcalinas. Acreditava-se até há pouco tempo atrás que este seria o seu único modo importante de ocorrência.

Os complexos representados por zonas lineares de carbonatitos, perlongam falhas profundas por dezenas de quilómetros e diferenciamse em muitos aspectos dos do Tipo Central. A análise das condições de localização e distribuição espacial mostrou que eles se formaram em estágio pré-plataformal, isto é, em condições tectônicas de cinturões móveis, podendo ser tanto intrusivos, quanto extrusivos (Lapin \& Ploshko 1988)

Esses dois tipos morfológicos de carbonatitos distinguem-se, também, no que tange à sua composição petrológica, mineralógica e mineralização endógena associada.

Os complexos do Tipo Central são notoriamente conhecidos e foram exaustivamente descritos em várias monografias e inúmeros artigos (Heinrich 1968, Tuttle \& Gittins 1968, Verwoerd 1967, Borodin 1974, Lê Bas 1978, Bell 1989, Woolley 1987, Kogarko et al. 1995, Epstein 1994, Lapin \& Tolstov 1995) e não serão aqui analisados em pormenor.

Entretanto, os complexos lineares, porque eram tidos como raros, foram considerados durante muito tempo meras curiosidades geológicas. Nos últimos quinze anos, muitos desses complexos sui generis foram descobertos e estudados (principalmente na Rússia, Ucrânia e no Canadá), verificando-se serem muito mais comuns que inicialmente imaginado, ganhando com isso uma nova dimensão, não só científica como económica. Descreveremos abaixo, e de modo sucinto, alguns dos complexos carbonatítico-feníticos lineares mais representativos do mundo, objetivando com isso chamar a atenção da comunidade geológica brasileira para esse tipo de magmatito, ao qual se associam por vezes importantes depósitos minerais de $\mathrm{P}, \mathrm{Nb}, \mathrm{TR}$, etc.

ZONA LINEAR CARBONATÍTICO-FENÍTICA TATARSKAYA Essa zona carbonatítico-fenítica localiza-se na parte Cen-

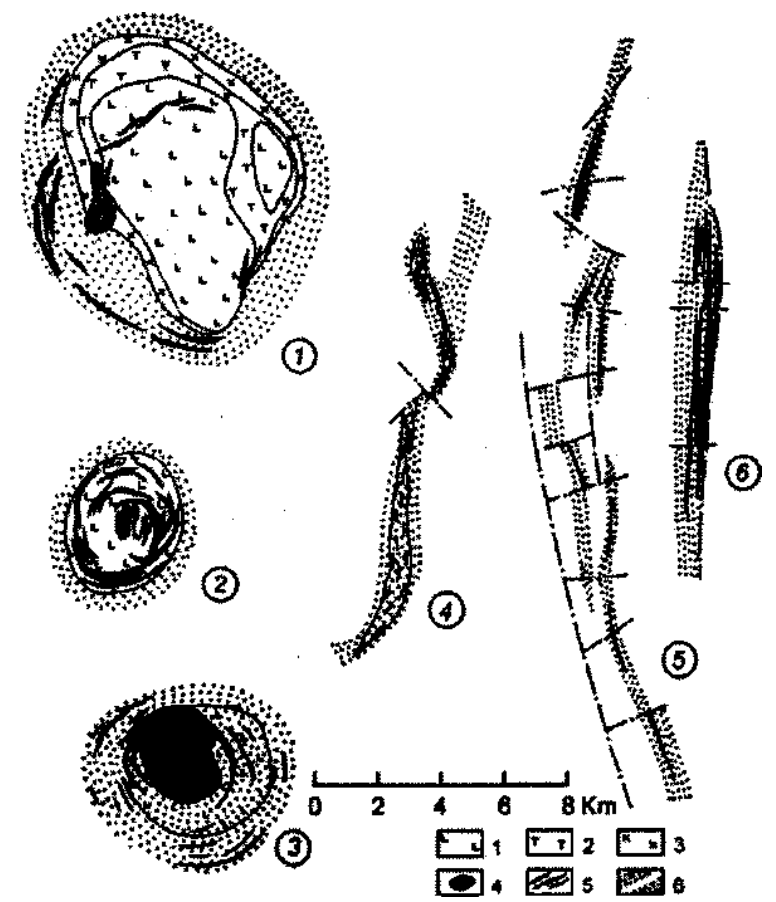

Figura l - Tipos morfológicos de complexos carbonatíticos. Números na figura: 1-3. Complexos carbonatiticos do "Tipo Central", 1.Kovdor (Kukharenko et al. 1965), 2. Glenover (Verwoerd 1967), 3. Sokli (Vartiainen \& Paarma 1979); 4-6. Zonas lineares de carbonatitos e metassomatitos alcalinos. 4. Siilinjärvi (Puustinen 1971), 5. Zona Tatarskaya (Lapin et al. 1987), 6. Zona de Chernigov (Glevasskiy \& Krivdik 1981)

Institute of Mineralogy, Geochemistry and Crystallochemistry of Rare Elements - IMGRE, Veresaev 15, Moscow, 121257 - Rússia

Universidade Federal de Ouro Preto, Escola de Minas, Departamento de Geologia, CEP 35400-000, Campus Morro do Cruzeiro s/n, Ouro Preto, MG, Brasil

Endereco atual: Rua Luiz Tolezano N²23, CEP 09400-000, Ribeirão Pires, SP, Brasil 
trai, soerguida, da Cadeia de Montanhas do Yenissei, a qual faz parte da faixa de dobramentos do Cinturão Baikaliano, que bordeja pelo sul a Plataforma Siberiana (Rússia). A intrusão dos corpos carbonatíticos ocorreu ao longo da zona de falhas profundas e paralelamente à elongação dos principais elementos estruturais da Cadeia de Montanhas do Yenissei, na região da borda ocidental do Anticlinório Central onde afloram rochas do embasamento (pré-baikaliano). Os carbonatitos estendem-se pela zona de falhas por mais de $20 \mathrm{~km}$, numa faixa de 2-2,5 km de largura (Fig.2). As rochas encaixantes são representadas por metassedimentos terrígeno-carbonáticos do Mesoproterozóico, nas quais se alojaram corpos tabulares concordantes de gabróides. Essas rochas acham-se metamorfizadas até o início da fácies anfibolito baixo, e apresentam-se estruturadas à moda de um monoclinal com a parte ocidental exibindo alto ângulo de mergulho. No âmbito da zona linear carbonatítico-fenítica, os carbonatitos ocorrem na forma de uma série de corpos tabulares alongados e isoorientados, concordantes com as rochas metassedimentares do Mesoproterozóico, com dimensões máximas atingindo $2,5 \mathrm{~km}$ de comprimento e espessuras que alcançam $120 \mathrm{~m}$ (Lapin et al. 1987).

As estruturas que controlam as intrusões carbonatíticas são representadas pelas superficies de contato de unidades litológicas diferentes ou por interfaces do acamamento

A composição mineralógica dos carbonatitos é relativamente simples, sendo representada por minerais formados em um único estágio

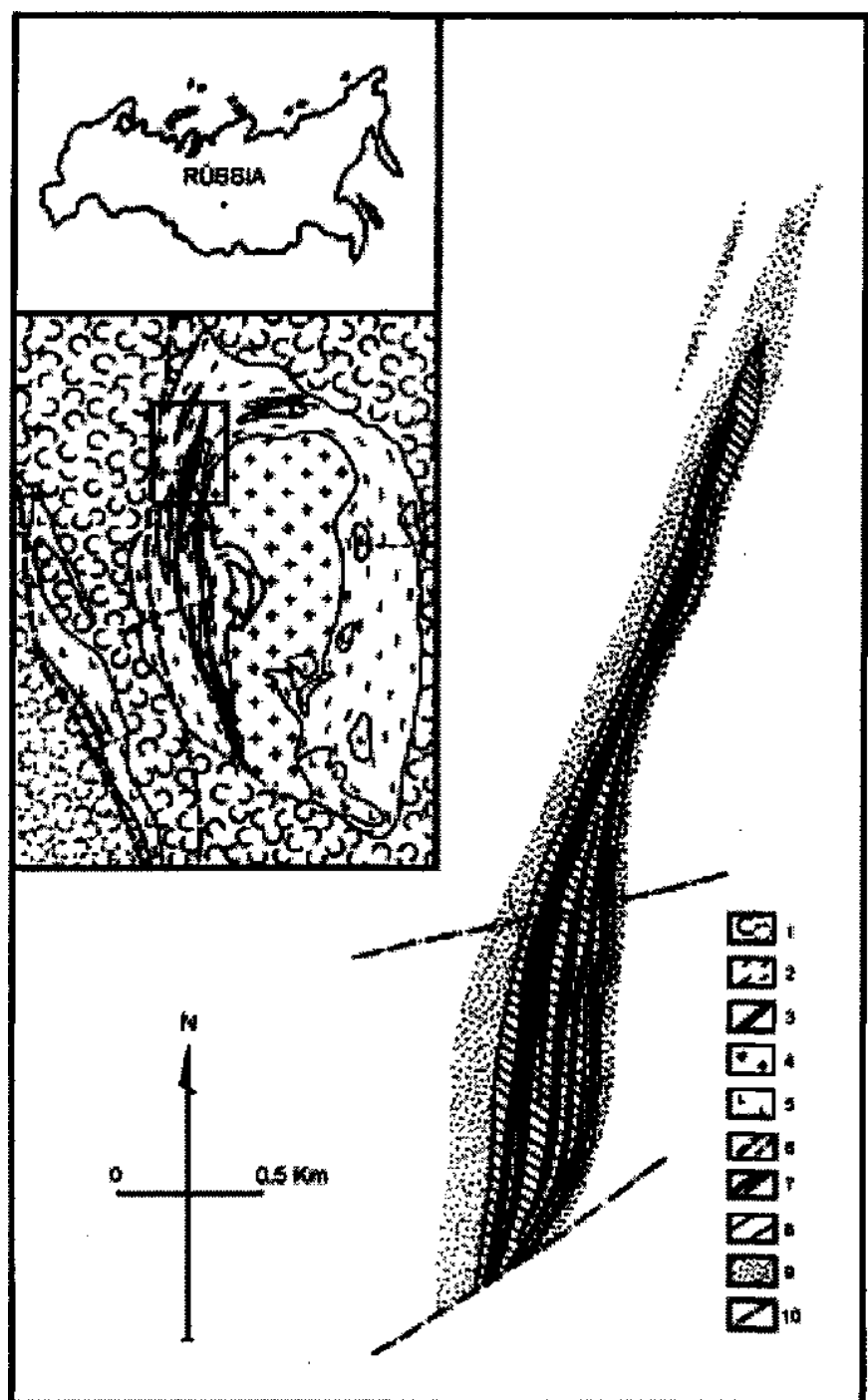

Figura 2 - Esboço geológico da Zona Linear Carbonatítico- Fenítica Tatarskaya, em detalhe o seu segmento setentrional, l- complexo metamórfico do Toniano-Esteniano; 2 - complexo metamórfico do pré-Calimiano; 3 - rochas alcalinas; 4 - granitóides; 5 - ortoanfibolitos; 6 - zona de falhas profundas; 7 - carbonatitos; 8 - slyuditos; 9 fenitos silicáticos e fenitos apomármores; 10- estruturas disruptivas (Lapin et al. 1987). e pertencentes a uma só fácies de temperatura: ferro-dolomita, magnésio-arfvedsonita, flogopita, apatita, pirrotita; em alguns setores surgem ainda magnetitae tetraferriflogopita; como acessórios ocorrem pirocloro, zircão, ilmenorutilo, e às vezes columbita e fersmita. A composição química dos carbonatitos e de seus minerais constituintes acha-se na Tabela 1 .

As rochas carbonatíticas apresentam notória especialização geoquímica expressa pelo considerável enriquecimento em fósforo, nióbio, terras raras céricas $\left(\mathrm{TRc}_{\mathrm{c}}\right.$, estrôncio, bário, manganês e, em menor grau, em zircônio. Os valores das relações isotópicas de carbono $\left(\delta C^{13}=-5 \%\right)$, oxigénio $\left(\delta \mathrm{O}^{18}=9,3\right)$ e estrôncio $\left(\mathrm{Sr}^{87} / \mathrm{Sr}^{86}=0,7020\right)$ estão dentro dos parẩmetros esperados para rochas formadas no manto.

Esses carbonatitos não têm vínculo com rochas alcalinas magmáticas mas acham-se acompanhados por auréolas ou orlas de metassomatitos alcalinos que, em termos de possança, se equiparam aos próprios carbonatitos. Nos locais de acunhamento dos corpos carbonatíticos, a zona de metassomatitos ainda se estende por considerável distância. A composição dos metassomatitos é determinada pela composição inicial das rochas encaixantes, representadas por quartzo-biotita xistos, xistos a duas micas, mármores, calcíferos com lentes de mármores dolomíticos, bem como por corpos tabulares de metagabros (anfibolitos). A composição química dos tipos mais comuns de metassomatitos aí encontrados pode ser vista na Tabela 1 . Enquanto, os principais tipos faciológicos de metassomatitos alcalinos podem ser vistos na Tabela 2. Quanto aos mecanismos de formação dos metassomatitos, distinguem-se dois tipos: os de infiltração e os de infiltração-difusão. No contato dos carbonatitos dolomíticos com rochas alumossilicáticas, formam-se slyuditos (rochas melanocráticas de origem metassomática constituídas por micas pretas, Paffengolts 1973 e Bhatnagar 1991) contato-reacionais (infiltração-difusão) e metassomatitos anfibólioflogopíticos. A parte externa da auréola é constituída por metassomatitos infiltracionais.

A intrusão dos carbonatitos e a formação dos metassomatitos ocorre em ambiente de tensão tectônica na zona da falha ativa, fato que promove neles o desenvolvimento de textura traquítica orientada ou gnáissica, ambas concordantes com as atitudes das rochas encaixantes.

A determinação da idade dos carbonatitos pelo método $\mathrm{Pb}-\mathrm{Pb}$, indica 1.000 m.a., cifra que corresponde à principal fase de dobramento da Cadeia do Yenissei, no limite do Mesoproterozóico com o Neoproterozóico. Dados radiométricos obtidos pelo método K-Ar em flo-

Tabela l - Composição química dos carbonatitos e dos metassomatitos da Zona Tatarskaya (Lapin et al 1987).

\begin{tabular}{|l|cc|c|c|c|}
\hline \multicolumn{1}{|c|}{ Componentes } & 1 & 2 & 3 & 4 & 5 \\
\hline $\mathrm{SiO}_{2}$ & 3,58 & 12,04 & 31,07 & 53,28 & 13,30 \\
$\mathrm{TiO}_{2}$ & 0,08 & 0,16 & 0,47 & 0,36 & 0,20 \\
$\mathrm{Al}_{2} \mathrm{O}_{3}$ & 1,40 & 3,67 & 8,91 & 10,26 & 4,79 \\
$\mathrm{Fe}_{2} \mathrm{O}_{3}$ & 3,58 & 5,73 & 6,06 & 4,76 & 3,36 \\
$\mathrm{FeO}^{\mathrm{O} O}$ & 5,03 & 2,58 & 5,20 & 3,62 & 0,58 \\
$\mathrm{MnO}$ & 0,94 & 0,63 & 0,12 & 0,16 & 0,49 \\
$\mathrm{MgO}$ & 20,81 & 17,05 & 13,18 & 3,28 & 4,66 \\
$\mathrm{CaO}$ & 26,51 & 24,78 & 11,70 & 8,90 & 38,97 \\
$\mathrm{Na}_{2} \mathrm{O}$ & 0,50 & 1,07 & 1,88 & 8,40 & 2,98 \\
$\mathrm{~K}_{2} \mathrm{O}$ & 0,94 & 2,40 & 6,28 & 0,10 & 0,24 \\
$\mathrm{P}_{2} \mathrm{O}$ & & 6,21 & 5,76 & 0,24 & 0,19 \\
$\mathrm{CO}$ & 35,50 & 21,55 & 5,20 & 5,89 & 29,71 \\
$\mathrm{H}_{2} \mathrm{O}^{*}$ & & & 0,23 & & \\
$\mathrm{H}_{2} \mathrm{O}^{+}$ & 0,83 & 1,69 & 1,93 & 0,28 & 0,36 \\
$\mathrm{~F}$ & 0,48 & 1,43 & 1,35 & - & 0,40 \\
$\mathrm{~S}$ & 0,47 & 0,37 & 1,07 & 1,34 & 0,25 \\
$\Sigma$ & 100,65 & 101,36 & 100,94 & 100,87 & 100,63 \\
$-\mathrm{O}=\mathrm{F}_{2}$ & 0,20 & 0,60 & 0,57 & - & 0,17 \\
$-\mathrm{O}=$ & 0,24 & 0,18 & 0,54 & 0,66 & 0,12 \\
$\Sigma$ & 100,21 & 99,63 & 99,63 & 100,21 & 100,34 \\
\hline
\end{tabular}

1- Carbonatito dolomítico pegmatóide; 2- carbonatito dolomítico gnaissóide; 3- rocha flogopítico-arfvedsonítica reacional de contato 4- metassomatito anfibólio-albítico apoxisto; 5- metassomatito anfibólio-calcítico desenvolvido sobre mármores. 
gopita indicam 640-660 m.a. (Neoproterozóico III), idade correspondente ao período final da evolução orogênica da Cadeia do Yenissei.

Os parâmetros das condiç̃es de cristalizacão dos carbonatitos foram determinados pelo método da crepitação das inclusões líquidogasosas e pelo geotermobarômetro dolomita-calcita (Talantsev 1981), fornecendo os seguintes valores: $530-620^{\circ} \mathrm{C}$ e $2,4-2,8 \mathrm{kbar}$. Além das texturas e estruturas singenéticas (traquítica e gnáissica) foram identificados nos carbonatitos e metassomatitos, sinais de ação tectônica disruptiva posterior.

As fases terminais do dobramento rifeano (Neoproterozóico III) provocaram a deformação dos carbonatitos formando mega-constrições e alargamentos (pinch and swell) dos corpos. A deformação em alguns setores da zona foi intensa a ponto de transformar os carbonatitos em milonitos típicos. Os metassomatitos calcíticos apomármores (apo- prefixo à partir, às expensas, derivado de, indica a partir de que rocha original se formou a nova; exemplo: fenito apognáissico), por serem menos competentes que as demais rochas, sofreram fluxo plástico com desenvolvimento de fino enrugamento (dobras de arrasto). Posteriormente, mas antes da ruptura responsável pela brechação dos carbonatitos ao longo de zonas oblíquas à sua elongação (falhas en echelon), estes sofreram diaftorese de fácies actinolita-clorita na qual ocorreu a cloritização dos minerais silicáticos fêmicos, e a fersmitização e columbitização do pirocloro.

No período terminal de sua evolucão, a zona carbonatítico-metassomática foi compartimentada em vários blocos tectônicos (altos e baixos), por falhas transversais e longitudinais em relação à sua elongação, simultaneamente à formação do manto de intemperismo.

Nos blocos tectônicos que sofreram efetivo soerguimento, o intemperismo levou à formação de mantos de alteração de fácies de hidromicas de pequena espessura, enquanto que nos blocos deprimidos ou passivos, formaram-se coberturas lateríticas maduras e espessas.

A mineralização economicamente rentável de nióbio e fosfatos encontra-se tanto nos mantos de intemperismo, quanto nos carbonatitos primários, e forma dois corpos de minério. No corpo $\mathrm{N}^{\circ} 1$, situado na porção norte do complexo, há nas lateritas 4 milhões de toneladas de minério com $0,61 \%$ de $\mathrm{Nb}_{2} \mathrm{O}_{5}$ e $8,20 \%$ de $\mathrm{P}_{2} \mathrm{O}_{5}$, já no de $\mathrm{N}^{\circ} 2$ localizado no setor sul, foram bloqueadas 6,7 milhões de toneladas com 1,20-2,50\% de $\mathrm{Nb}_{2} \mathrm{O}_{5}$ (pirocloro e columbita) e 6,5 milhões de toneladas de minério composto por francolita, limonita- francolita com $23,70 \%$ de $\mathrm{P}_{2} \mathrm{O}_{5}$ (Lapin \& Tolstov 1995).

Como características intrínsecas dos carbonatitos lineares da Zona Tatarskaya, podemos citar as seguintes: possuem clara e notável forma linear; associação com uma zona de falhas profundas, na qual os carbonatitos se estendem por dezenas de quilómetros; não têm associação com rochas magmáticas alcalinas, mas acham-se envoltos por possantes auréolas de metassomatitos alcalinos; disposição concordante em relação às rochas metassedimentares; a zona, como um todo, estende-se paralela à estruturação geral do cinturão móvel; a intrusão (dos carbonatitos) corresponde à fase pré-orogênica; apresentam uma composição mineralógica relativamente simples, com uma fácies petrográfica e um único estágio de intrusão.

ZONA DE CARBONATITOS DE CHERNIGOV Complexo Carbonatítico de Chernigov localiza-se em uma zona tectônica de alta permeabilidade, que separa o Bloco de Priazov (integrante do Escudo Ucraniano ), de idade arqueana, da Faixa de Dobramentos (vulcano- plutônica) Orekho-Pavlograd, do Paleoproterozóico. Essa zona de falhas identifica-se claramente pelas assinaturas dos seus campos magnético e gravitacional, e é interpretada como região de soerguimento escalonado da superficie $\mathrm{M}$ do manto, caracterizando-se por uma complexa combinação de estruturas lineares e anelares do Arqueano e Paleoproterozóico (Baluev 1986).

Dentre os complexos lineares, o de Chernigov é o mais antigo (1.820-2.000 m.a.) e de maior nível de erosão (estimado em mais de $10 \mathrm{~km}$ ). Ele se formou após o término da sedimentação do Cinturão Orekho-Pavlograd, mas antes da fase principal de deformação e consolidação do Escudo Ucraniano. Os carbonatitos são praticamente síncronos à granitização do fim do Paleoproterozóico e à fase de ultrametamorfismo do Complexo de Priazov (1.800-2.150 m.a.), após o que, ocorreu a consolidação dessa região e a formação de uma crosta continental "madura". Uma estrutura típica de granitização é o Domo Granito-gnáissico de Elisseev, com cerca de $35 \mathrm{~km}$ de diâmetro, que se localiza $10 \mathrm{~km}$ a sudeste dos carbonatitos.

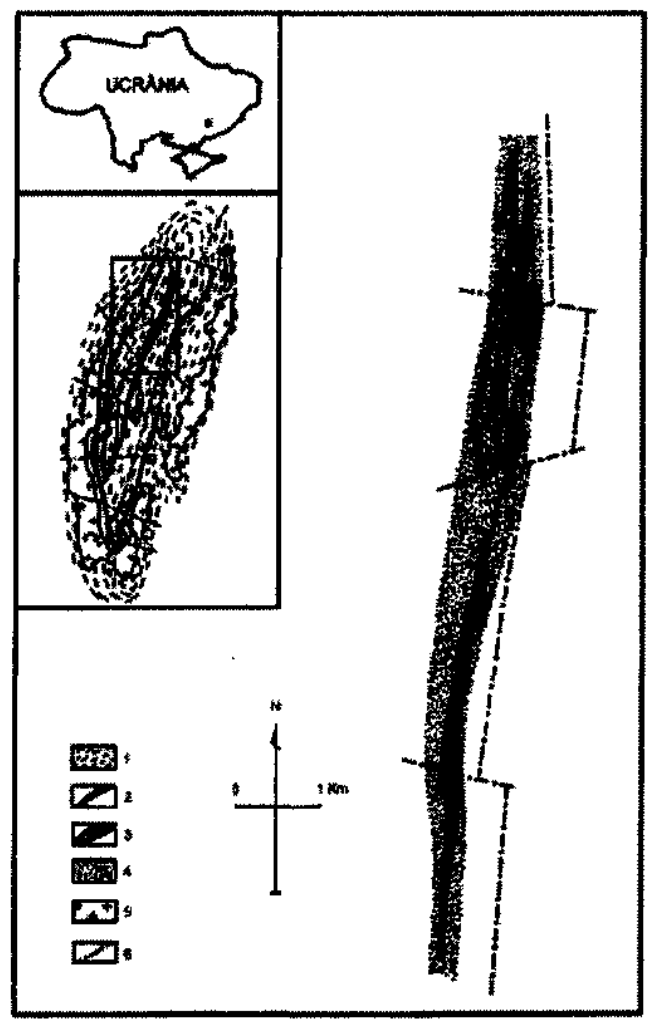

Figura 3 - Esboço geológico do Complexo de Chernigov, em detalhe a área de Novopoltava (Russakov,N.F.; Kravchenko.G.L. \& Lyagushkin,LP. inédito). 1- gnaisses e migmatitos do Arqueano; 2 carbonatitos; 3 - albititos; 4 -fenitos; 5 - granitóides do Complexo de Priazov; 6 - estruturas disruptivas.

Tabela 2 - Principais fácies de metassomatitos.

\begin{tabular}{|c|c|c|c|c|c|c|}
\hline $\begin{array}{c}\text { Rochas } \\
\text { Enctixintes }\end{array}$ & \multicolumn{3}{|c|}{ Zona de Metascomatitos de Infiltraçin } & 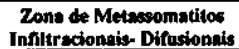 & $\begin{array}{l}\text { Zonin de Endocontalo } \\
\text { de Rachas Hibrides }\end{array}$ & $\begin{array}{c}\text { Magma } \\
\text { Carbonatítico }\end{array}$ \\
\hline $\begin{array}{c}\text { Quartzo-biotita } \\
\text { Xisto }\end{array}$ & $\begin{array}{c}+\mathrm{N}_{2}, \mathrm{Fe}_{1} \mathrm{CO}_{2}, \mathrm{~F} \\
\text { Anfibuilio Ieldspato fen } \\
\text { (Anf } \pm \mathrm{Kfelds}+\mathrm{Ab}+ \\
=\mathrm{H}_{2} \mathrm{O}, \mathrm{S}\end{array}$ & \multicolumn{2}{|c|}{ 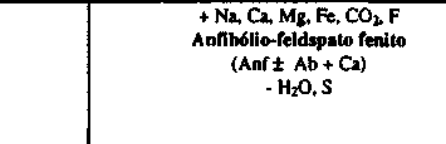 } & $\begin{array}{c}+\mathrm{K}, \mathrm{Na}, \mathrm{Ca}, \mathrm{Mg}, \mathrm{Fe} \mathrm{c}_{2} \\
\mathrm{CO}_{2,} \mathrm{H}_{2} \mathrm{O}, \mathrm{P}, \mathrm{F}_{7} \mathrm{~S} \\
\text { Slyudito } \\
(\mathrm{Anf}+\mathrm{Fl}+\mathrm{Ca}+\mathrm{Dol}+\mathrm{An}) \\
-\mathrm{S}\end{array}$ & $\begin{array}{l}\text { +Si, Al } \\
\text { Carbonatito gnaissolide } \\
-\mathrm{Ca}, \mathrm{MZ}, \mathrm{Fe}, \mathrm{CO}_{2}, \mathrm{P}, \mathrm{F}, \mathrm{S}\end{array}$ & \multirow{4}{*}{$\begin{array}{l}\text { Carbunatito } \\
\text { dolamítico } \\
\text { porfaritico } \\
\text { ou Iraquítico }\end{array}$} \\
\hline Ortosnfibalito & 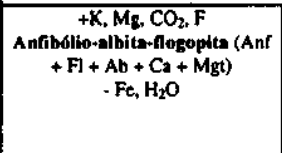 & $\begin{array}{c}+\mathrm{K}, \mathrm{Na}_{1}, \mathrm{Mg}_{2} \mathrm{CO}_{2} \mathrm{~F} \\
\text { Flapopita-albita } \\
(\mathrm{Fl}+\mathrm{Ab}+\mathrm{Ca}) \\
-\mathrm{Ca}, \mathrm{Fe}, \mathrm{H}_{2} \mathrm{O}\end{array}$ & $\begin{array}{c}+\mathrm{Na}, \mathrm{Ca}_{1} \mathrm{CO}_{2,} \mathrm{~F} \\
\text { Albitilo } \\
(\mathrm{Ab} \pm \mathrm{F}+\mathrm{Ca}) \\
\text { - Si, K, } \mathrm{Mg}, \mathrm{Fe}\end{array}$ & & & \\
\hline $\begin{array}{l}\text { Márphore } \\
\text { Culciticil }\end{array}$ & \multicolumn{3}{|c|}{ 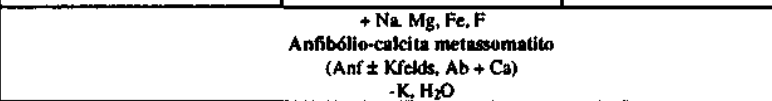 } & 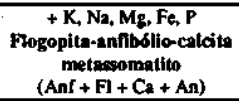 & $\begin{array}{l}\text { Frequentemente } \\
\text { intercalacto de } \\
\text { carbonatitose } \\
\text { metromomatitus }\end{array}$ & \\
\hline $\begin{array}{l}\text { Mármone } \\
\text { Dolomiticen }\end{array}$ & \multicolumn{3}{|c|}{ 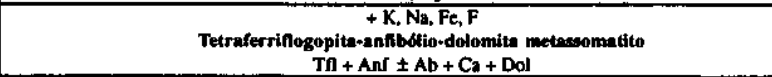 } & & & \\
\hline
\end{tabular}

Ab - albita; An - anortita; Anf- anfibólio; Ca - calcita; Dol - dolomita; Fl - Flogopita; Kfelds - feldspato potássico; Mgt - magnetita; Tfl - tetraferriflogopita 
A localização do complexo carbonatítico é controlada pela Falha de Chernigov, que é integrante de um feixe de falhas que constitui a Zona de Falhas Profundas de Chernigov. No âmbito da Falha de Chernigov, há várias ocorrências de carbonatitos e metassomatitos alcalinos que se lhes associam. Os carbonatitos estendem-se submeridianamente ao longo de uma zona de mais de $30 \mathrm{~km}$ de comprimento, dispõem-se subconcordantemente com as rochas hospedeiras arqueanas e apresentam fortes mergulhos, predominantemente voltados para leste (Fig. 3)

O maior corpo carbonatítico é o de Novopoltava. Ele acha-se recoberto por um manto de intemperismo e por sedimentos mesocenozóicos, que alcançam $150 \mathrm{~m}$ de espessura. Segundo dados de sondagem, os metassomatitos alcalinos formam uma estreita faixa que se estende por mais de $10 \mathrm{~km}$ ao longo da Falha de Chernigov, envolvendo os outros corpos tabulares de carbonatitos subverticais de até $5 \mathrm{~km}$ de comprimento e possança de $50-150 \mathrm{~m}$. Esses carbonatitos alojam-se subconcordantemente às estruturas dos gnaisses, xistos, anfibolitos e migmatitos do Arqueano.

A auréola fenítica tem estruturação zonada. A zona externa de fenitos desenvolvida sobre rochas portadoras de quartzo (gnaisses e migmatitos) tem estruturação lenticular bandada, constituída de albitaoligoclásio, hastingsita e egirina-augita. $\mathrm{Na}$ zona intermediária, mantém-se a gnaissificação reliquiar (textura phantom), mas, onde 0 quartzo está ausente, aparece notável quantidade de feldspato potássico. Na zona interna, os fenitos apresentam estrutura maciça, sendo constituídos por agregado granular hipidiomórfico de anortoclásio e egirina-augita, com raros e uniformemente distribuídos grãos e agregados de calcita e apatita. Os fenitos proximais são indistingüíveis, na aparência, dos sienitos intrusivos. Nas partes axiais do complexo carbonatítico-fenítico, as rochas encaixantes que sofreram as transformações mais intensas, apresentam biotita e rara nefelina disseminada. Os anfibolitos no processo de fenitização transformam-se em anfibólio-piroxênio fenitos com pequena quantidade de feldspatos e nefelina.

Os carbonatitos da região de Novopoltava (exceto as vênulas carbonáticas tardias), são representados por duas variedades mineralógicas, alvikitos e beforsitos, as quais se alternam no âmbito dos corpos carbonatíticos. Os carbonatitos calcíticos (alvikitos) tendem a se localizar nos bordos, enquanto que os calcítico-dolomíticos e dolomíticos (beforsitos), tendem a constituir a massa predominante dos mesmos.

A relação entre os carbonatos nas rochas encontra-se próxima do estado de equilíbrio termodinâmico (disseminacão uniforme, idiomorfismo dos grãos, intercrescimentos gráficos). Tanto uns como outros apresentam a mesma assembleia de minerais formadores de rocha, bem como de minerais acessórios: apatita, olivina, flogopita, magnetita, ilmenita, pirrotita, Ce-fergusonita, U-pirocloro, baddeleita, zircão e grafita. Nas zonas do endocontato, ao lado da flogopita e olivina, aparecem também, egirina-diopsídio e cataforita (Glevaskiy \& Krivdik 1981, Kapustin et al. 1977, Vilkovich \& Pozharitskaya 1986). Os carbonatitos mesocráticos apresentam textura granular grossa, homogénea. Raramente apresentam listras e fitas formadas pela concentração de minerais silicáticos escuros e magnetita, e mais raramente formam bandas alternadas constituídas por apatita-flogopita-olivina e apatita-magnetita, que alcançam vários metros de espessura.

São raros os contatos bruscos dos carbonatitos com os fenitos encaixantes pois, no mais das vezes, estão separados por uma camada reacional de anfibólio-flogopita e olivina-flogopita-nefelina cuja espessura pode variar de $1 \mathrm{a} 20 \mathrm{~cm}$. Por outro lado, os próprios fenitos acham-se albitizados até uma distância de no máximo $5 \mathrm{~m}$ do seu contato com os carbonatitos. Em muitos casos, os fenitos acham-se brechados e os carbonatitos híbridos próximo dos contatos apresentam fragmentos angulosos e arredondados de fenitos flogopitizados que alcançam até $20 \mathrm{~cm}$ no seu eixo maior. A composição química dos carbonatitos e fenitos do trecho de Novopoltava, da Zona Carbonatítico-Fenítica de Chernigov, pode ser vista, na Tabela 3 .

A temperatura de formação dos carbonatitos, baseada em minerais geotermómetros, foi estimada em $600-750{ }^{\circ} \mathrm{C}$ (Bagdasarov et al. 1982). Há avaliações com resultados diferentes, mas com valores próximos (Glevasskiy \& Krivdik 1981). Como já citado anteriormente, a profundidade do corte de erosão do Complexo CarbonatíticoFenítico de Chernigov está estimada em mais de 10 km (Glevasskiy \& Krivdik 1981).

Os estudos mineralógicos detalhados mostraram que existe expressiva variação no índice de ferricidade nos silicatos, magnetita e ilmenita coexistentes (Bagdasarov et al. 1982, Glevasskiy \& Krivdik 1981), bem como foi possível identificar processos superpostos de escarnitização acompanhados pela desdolomitização dos carbonatitos no contato com as rochas silicaticas (Vilkovich \& Pozharitskaya 1986) e a substituição do pirocloro pela fergusonita (Nechelyustov \& Pozharitskaya 1986 ). Estas feições, ao que tudo indica, se devem à ação das fases finais de granitização do Complexo de Priazov, temporalmente síncrono com os carbonatitos. Cabe ressaltar que ambos localizam-se nas mesmas estruturas da Zona Tectônica do Priazov Ocidental.

Segundo Lapin \& Tolstov (1995) só nos mantos de intemperismo desse carbonatito foi bloqueada uma reserva de minério de 100 milhões de toneladas com $0,32 \%$ de $\mathrm{Nb}_{2} \mathrm{O}_{5}$ (pirocloro e Ce-fergusonita)e 9,00 $\%$ de $\mathrm{P}_{2} \mathrm{O}_{5}$ (apatitas com $\pm 0,60 \%$ de $\mathrm{TR}_{\mathrm{Ce}}$ )

Destarte, o Complexo Carbonatítico-Fenítico de Chernigov, nos seus traços gerais, assemelha-se muito ao Complexo CarbonatíticoFenítico da Zona Tatarskaya, diferenciando-se nas condições geotermobarométricas de formação (temperatura e pressão superiores).

COMPLEXO CARBONATÍTICO ANGICO DOS DIAS O complexo carbonatítico Angico dos Dias situa-se na faixa de dobramentos Riacho do Pontal, que bordeja a porção norte do Cráton do São Francisco (Alkmin et al. 1993), e localiza-se no município de Campo Alegre de Lourdes, no NNW do Estado da Bahia, próximo dos seus confins com o Estado do Piauí.

A intrusão do complexo carbonatítico nas rochas gnáissico-migmatíticas do Paleoproterozóico que constituem o embasamento da faixa Riacho do Pontal (Silva et. al 1988, Leite \& Santos 1994) é controlada por falhas de direção NE (Silva et al. 1988). Os carbonatitos formam dois corpos principais com direção geral N20E e mergulhos predominantes para $\mathrm{NW}$, com ângulos inferiores a $45^{\circ}$. O menor, em forma de lente, situado a oeste tem cerca de $960 \mathrm{~m}$ de comprimento, e ao redor de $180 \mathrm{~m}$ na sua parte mais larga. O maior, localizado a leste, é delgado na sua porção sul e central, onde tem larguras aparentes variando de 53 a $95 \mathrm{~m}$, e na porção norte ele alarga-se atingindo cerca de $360 \mathrm{~m}$, e expõe-se ao longo de $2070 \mathrm{~m}$. As reais dimensões dos carbonatitos são desconhecidas, pois a norte eles se acham recobertos por arenitos de idade Terciária-Quaternária e a sudeste estão sotopostos a arenitos e conglomerados da Formação Serra Grande, de idade Siluro-Devoniana. (Fig. 4).

Esses carbonatitos foram submetidos a pelo menos duas fases de deformação. O primeiro dobramento apresenta eixo de direção NE-

Tabela 3 - Composição química dos carbonatitos e fenitos da região de Novopoltava - Zona Carbonatítica de Chernigov (Glevasskiy \& Krivdik 1981).

\begin{tabular}{|l|c|c|c|c|}
\hline \multicolumn{1}{|c|}{ Componentes } & 1 & 2 & 3 & 4 \\
\hline $\mathrm{SiO}_{2}$ & 13,69 & 8,53 & 8,10 & 60,61 \\
$\mathrm{TiO}_{2}$ & 0,37 & 0,47 & 0,16 & 0,66 \\
$\mathrm{Al}_{2} \mathrm{O}_{3}$ & 3,34 & 1,46 & 1,91 & 15,03 \\
$\mathrm{Fe}_{2} \mathrm{O}_{3}$ & 2,22 & 3,21 & 5,25 & 2,27 \\
$\mathrm{FeO}$ & 4,25 & 5,03 & 6,26 & 2,53 \\
$\mathrm{MnO}$ & 0,54 & 0,39 & 0,71 & 0,07 \\
$\mathrm{MgO}$ & 3,58 & 5,66 & 10,78 & 1,93 \\
$\mathrm{CaO}$ & 39,42 & 40,31 & 32,66 & 4,78 \\
$\mathrm{BaO}$ & 0,05 & 0,03 & 0,15 & - \\
$\mathrm{Na}_{2} \mathrm{O}$ & 1,03 & 0,35 & 0,27 & 7,48 \\
$\mathrm{~K}_{2} \mathrm{O}$ & 1,34 & 0,95 & 1,02 & 2,50 \\
$\mathrm{P}_{2} \mathrm{O}_{5}$ & 3,50 & 4,78 & 3,44 & 0,12 \\
$\mathrm{~S}$ & 0,26 & 0,22 & 0,20 & 0,08 \\
$\mathrm{H}_{2} \mathrm{O}$ & 0,15 & 0,12 & 0,14 & 0,15 \\
$\mathrm{Perda}$ ao fogo & 0,81 & 1,21 & 1,08 & 0,89 \\
$\mathrm{CO}$ & 25,74 & 27,02 & 27,93 & 0,72 \\
$\mathrm{C}$ (grafita) & n. d. & n. d. & n. d. & - \\
$\mathrm{F}$ & 0,22 & 0,31 & 0,30 & - \\
Soma & 100,39 & 99,75 & 99,98 & 99,78 \\
\hline
\end{tabular}

n.d. - não determinado

1-Sövito média de 18 análises;

2 alvikito média de 12 análises;

3 beforsito média de 22 análises;

4 fenito $\left(4^{\circ}\right.$ estágio) desenvolvido sobre granito-gnaisses. 
SW, e o segundo, eixo de direção NW-SE. Sua colocação na forma de um corpo tabular subvertical se deu em rochas encaixantes já dobradas em isoclinais com eixos de direção N-S (Silva et. al 1987), que foram afetadas no Brasiliano pela faixa Riacho do Pontal. No entanto, não se pode descartar a possibilidade de que uma das fases de dobramento que afetou o carbonatito seja do Paleoproterozóico, como apontam Leite \& Santos (1994).

A idade de colocação dos carbonatitos obtida pelo método U-Pb em baddeleyita e zircão acusou $2011 \pm 6$ m.a.(Silva et al. 1988), dado que os posiciona no Paleoproterozóico (Orosiriano). O complexo como um todo acha-se cortado por uma rede de diques lamprofíricos.

A composição dos carbonatitos de Angico dos Dias é relativamente simples, com minerais formados em um estágio e pertencentes a uma só fácies de temperatura. Petrograficamente eles são constituídos por sovítos ou cálcio carbonatitos (na acepção de Wooley \& Kempe 1989, In: Bell 1989), cuja assembleia de minerais é formada por calcita (predomina), dolomita, apatita verde clara com forma de ovóide, biotita, magnetita e pseudomorfos de olivina serpentinizada. Como acessórios e secundários exibem monazita, baddeleyita, antofilita, estroncianita, sulfetos (pirita, pirrotita e galena), whiterita, carbonatos de elementos de terras raras e celestita.

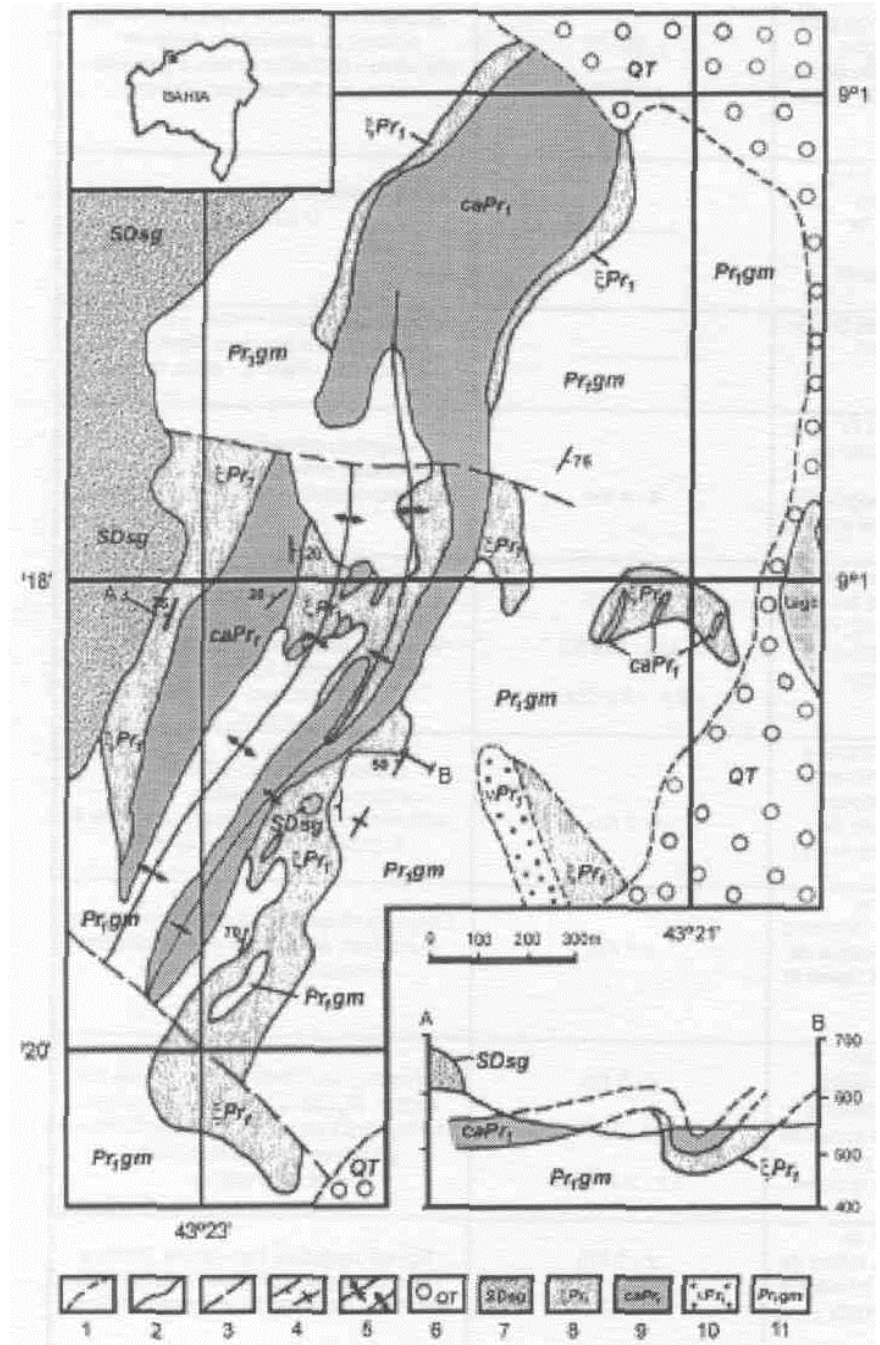

Figura 4 - Mapa geológico do Carbonatito Angico dos Dias (Silva et al. 1987 e 1988, modificado), 1- limite da cobertura superficial; 2 contato; 3 - falhas; 4 - direção e mergulho da foliação, direção da foliação vertical; 5 - eixo de sinclinal e eixo de anticlinal; 6 - arenitos ferruginosos de idade Ter ciar ia-Quaternária; 7 - arenitos e conglomerados da Formação Serra Grande de idade Siluro-Devoniana; 8 mica piroxenitos; 9 - carbonatito e crosta fosfática; 10 - fenitos com piroxenito subordinado; 11- embasamento gnáissico-migmatítico e rochas metagabróicas com niveis hornblendíticos.
Apresentam textura granular média a grossa, com a calcita podendo atingir até $10 \mathrm{~cm}$ de dimensão, quando não afetada por tectônismo e recristalização. A dolomita, que perfaz menos de $10 \%$ do volume dos carbonatos, ocorre como mineral intergranular e como exsolução na calcita. A apatita apresenta-se na forma de enclaves ou de leitos definidos, sugerindo acumulação magmática, e mui raramente na forma de cristais de até $15 \mathrm{~cm}$.

Esses carbonatitos sovíticos são pobres em $\mathrm{Mg}$ e $\mathrm{Ba}$, e apresentam notória especialização geoquímica externada pelo marcante enriquecimento em fósforo, e muito subordinadamente em $\mathrm{TR}_{\mathrm{Ce}}$ e $\mathrm{Zr}$. Os dados de relações isotópicas do carbono $\left(\delta C^{13}=-15\right.$ a $\left.-19 \%\right)$, oxigénio $\left(\delta \mathrm{O}^{18}=-6\right.$ a $\left.-7,4 \%\right)$ e estrôncio $\left(\mathrm{Sr}^{87} / \mathrm{Sr}^{86}=0,7036\right)$, coadunam-se com os encontrados em rochas congêneres.

Não obstante os autores que estudaram esse complexo carbonatítico (Silva et al. 1987, 1988) enfatizarem a inexistência de fenitos nele, descrevem uma aureola zonada de rochas sieníticas diversas. Assim, a fácies proximal é representada por uma rocha mista de carbonato e albita (biotita-calcita albititos), constituída de calcita, albita, biotita, apatita e outros minerais. A fácies intermediária é formada por albititos com textura granoblástica ou granoblástica em mosaico, nos quais ao lado da albita (albita-oligoclásio) como mineral majoritário, aparecem biotita, calcita, clinopiroxênio e apatita, e como acessórios calcita estronciana, feldspato potássico com bário, titanita, monazita, ilmenita, torita, allanita, epídoto, baddeleyita, pirita, galena, carbonato de terras raras, e como secundários barita, tremolita-actinolita. A fácies distai pode estar representada por quartzo sienitos com texturas cataclásticas, nos quais ao lado da albita e do quartzo que são os minerais predominantes, aparecem como acessórios e secundários biotita (orientada), barkevikita, apatita, titanita, ilmenita, epídoto, feldspato potássico com bário, sericita, carbonato e tremolita- actinolita, ou por álcalifeldspato sienitos com texturas granoblásticas, constituídos principalmente por feldspato potássico com bário micropertítico e clinopiroxênio (diopsídio), titanita e apatita, e exibindo como minerais acessórios e secundários hialofana, celsiana, albita, titanita, ilmenita $\mathrm{e}$ tremolita-actinolita.

Essa zoneografia dos sienitos sugere que não se trata de um cortejo de rochas magmáticas intrusivas, mas sim, de fenitos reomórficos e metassomáticos, produzidos pela acão do magma carbonatítico de alta temperatura rico em sódio e voláteis sobre milonito-gnaisses leucocráticos.

Além das rochas citadas, ocorrem encraves de piroxenitos e dioritos alcalinos, que acham-se esparsamente distribuídos nos carbonatitos e sienitos. Os piroxenitos chegam a formar um corpo de dimensões mapeáveis na porção SE do complexo.

Os dados de análises químicas dos principais tipos de rochas encontradas no âmbito do complexo carbonatítico encontram-se na Tabela 4.

Tabela 4 - Composição química dos carbonatitos, fenitos e das rochas encaixantes na área de Angico dos Dias (Silva et al. 1988).

\begin{tabular}{|lcc|ccc|c|}
\hline Componentes & 1 & 2 & 3 & 4 & 5 \\
\hline $\mathrm{SiO}_{2}$ & 6,84 & 56,12 & 57,77 & 63,70 & 71,80 \\
$\mathrm{TiO}_{2}$ & 0,24 & 0,42 & 0,50 & 0,29 & 0,21 \\
$\mathrm{Al}_{2} \mathrm{O}_{3}$ & 1,40 & 19,52 & 13,80 & 14,07 & 14,35 \\
$\mathrm{Fe}_{2} \mathrm{O}_{3}$ & 3,11 & 2,64 & 1,70 & 1,62 & 0,63 \\
$\mathrm{FeO}$ & 2,77 & 1,81 & 2,15 & 1,76 & 0,51 \\
$\mathrm{MnO}$ & 0,17 & 0,08 & 0.17 & 0,10 & 0,03 \\
$\mathrm{MgO}$ & 4,84 & 2,53 & 2,53 & 2,91 & 0,53 \\
$\mathrm{CaO}$ & 41,41 & 5,98 & 7,23 & 5,67 & 1,40 \\
$\mathrm{BaO}$ & 0,23 & 0,92 & 1,31 & 0,26 & 0,16 \\
$\mathrm{SrO}$ & 0,23 & 0,55 & 0,36 & 0,26 & 0,05 \\
$\mathrm{Na} \mathrm{Na}_{2} \mathrm{O}$ & 0,07 & 7,22 & 4,33 & 5,05 & 3,75 \\
$\mathrm{~K}_{2} \mathrm{O}$ & 0,63 & 1,32 & 5,20 & 2,40 & 5,75 \\
$\mathrm{P}_{2} \mathrm{O}_{5}$ & 9,61 & 0,32 & 0,92 & 0,14 & 0,25 \\
$\mathrm{CO}$ & 25,50 & 0,88 & 1,63 & 0,95 & 0,37 \\
$\mathrm{H}_{2} \mathrm{O}$ & 0,12 & 0,14 & 0,15 & 0,20 & 0,08 \\
$\mathrm{H}_{2} \mathrm{O}^{+}$ & 0,73 & 0,46 & 0,35 & 0,78 & 0,22 \\
$\mathrm{~F}$ & 0,73 & 0,11 & 0,13 & 0,21 & 0,02 \\
$\mathrm{~S}$ & 0,12 & 0,01 & 0,01 & 0,01 & 0,01 \\
$\mathrm{Total}$ & 100,91 & 100,22 & 100,34 & 100,38 & 100,12 \\
\hline
\end{tabular}

1- carbonatito-média de 8 análises; 2 - albitito-média de 5 análises; 3- álcali- felspato sienito-média de 3 análises; 4quartzo-sienito-média de 4 análises; 5- milonito gnaisse leucocrático- média de 2 análises. 
Os dois corpos carbonatíticos estão cobertos por um manto supergênico residual de crosta fosfática (apatitito). A mineralização de fósforo e $T_{\mathrm{Ce}}$ associada a apatita acha-se tanto na crosta fosfática, quanto no carbonatito primário no qual o teor de apatita varia de 16,5 a $32,5 \%$. O depósito de minério residual tem reservas medidas de 12,5 milhões de toneladas com teor de $15,4 \%$ de $\mathrm{P}_{2} \mathrm{O}_{5}$ (Silva et al. 1988).

TIPOMORFISMO DOS CARBONATITOS FORMADOS EM CINTURÕES MÓVEIS Os exemplos supracitados, bem como os dados de outros complexos carbonatíticos de faixas móveis apresentados na Tabela 5, permitem reconhecer uma série de características comuns a todos eles, as quais tipificam a sua composição, estruturação e condições de formação:

1 - os carbonatitos sintectônicos se destacam flagrantemente pela morfologia linear dos seus corpos, localizam-se ao longo de zonas de falhas profundas e, em geral, estendem-se por dezenas de quilômetros, chegando por vezes a se perlongar por mais de $100 \mathrm{~km}$ (Levin et al. 1978). São constituídos por sistemas de corpos lineares ou encurvados e que se alternam com as rochas encaixantes, com as quais se dispõem concordantemente.

Tabela 5 - Características de alguns complexos carbonatítico -feníticos.

\begin{tabular}{|c|c|c|c|}
\hline $\begin{array}{l}\text { Complexo, } \\
\text { Locellizagfio, Dimensäo } \\
\text { Idade Absoluta }\end{array}$ & Ambiente - Tectónico Estrutural & $\begin{array}{l}\text { Profundidade de } \\
\text { Colocactio e P e T do } \\
\text { Formapilo }\end{array}$ & Princlpais Tipos de Rochas \\
\hline $\begin{array}{l}\text { Aarkopidzhakiy } \\
\text { Aússia } \\
35 \times 3 \mathrm{Km} \\
\text { K - Ar } 390 \pm 12 \mathrm{m.a} \text {. } \\
\text { (Lapin inédito) }\end{array}$ & 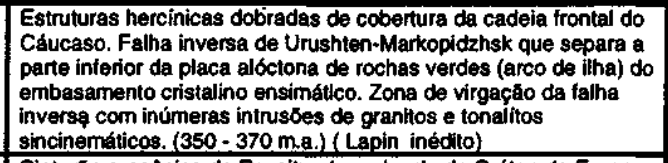 & Abissal & $\begin{array}{l}\text { Flogopita-hastingsita beforsitos com } \\
\text { apatita e rochas anfibólio flogopiticas do } \\
\text { exocontato e flogopita-piroxenio-anfibotio } \\
\text { fenitos aposserpentiniticos }\end{array}$ \\
\hline 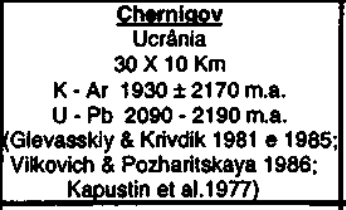 & 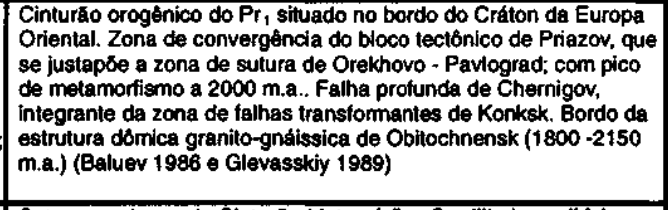 & $\begin{array}{l}>10 \mathrm{Km} \\
>620^{\circ} \mathrm{C} \\
>3,1 \mathrm{kbar}\end{array}$ & $\begin{array}{l}\text { Oivina-flogopita alvikitos e beforsitos com } \\
\text { apatita e U-piroctoro. Cancrinita-biolita } \\
\text { albititos do exocontato. Nefelina - } \\
\text { piroxénio - feldsperto ienitos e piroxénio - } \\
\text { teidspato tenitos apognássicos. }\end{array}$ \\
\hline $\begin{array}{c}\text { Verliy } \\
\text { Canada } \\
2,5 \times 0,14 \mathrm{Km} \\
\text { (Currie 1976; Pell \& Hoy 1989) }\end{array}$ & $\begin{array}{l}\text { Setor canadense do Claturso Metamórfico Cordilheirano (Mz), } \\
\text { Parte alóctonada da Plataloma Norte-Americana ("Terrain" } \\
\text { Silkirk). Cinturao Omineka com intrusdes sincinemáticas de } \\
\text { granitos nevadinianos (100-1 } 40 \text { m.a.), com janelas do } \\
\text { embesamento rifeano e núcleos de domos gnássicos ( Strulk } \\
1988 \text { ). }\end{array}$ & & $\begin{array}{c}\text { Olivina - anfibólio belorsitos com apatita e } \\
\text { U-pirocloro. }\end{array}$ \\
\hline $\begin{array}{l}\text { Songue scire } \\
\text { Tanzánia } \\
25 \times 1,6 \mathrm{Km} \\
\text { (Brown 1964) }\end{array}$ & 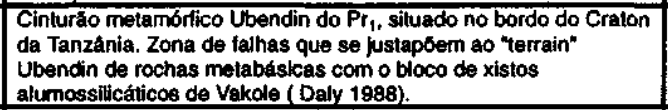 & & $\begin{array}{l}\text { Flogopita-anifibólio sovitos e beforsitos } \\
\text { com apatita e pirocloro. Albititos no } \\
\text { exocontato. Egirina - albita fenitos. }\end{array}$ \\
\hline $\begin{array}{c}\frac{\text { Newania }}{\text { India }} \\
>5 \times 1,2 \mathrm{Km} \\
\text { K- Ar } 959 \pm 24 \text { m.a. } \\
\text { ( Vilacker \& Wimmernauer 1984) }\end{array}$ & 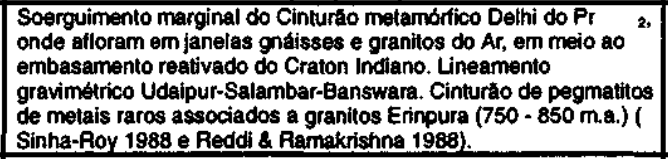 & $6.8 \mathrm{~km}$ & $\begin{array}{l}\text { Megnésio-srtvedsonita - flogopita } \\
\text { belorsitos com apatita e U-pirocloro. } \\
\text { Anfibólio-ortoclasio tenitos apognáissicos. }\end{array}$ \\
\hline $\begin{array}{l}\text { Renchenga } \\
\text { (Zona Tatarskaya) } \\
\text { Pússia } \\
70 \times 30 \mathrm{Km} \\
\mathrm{Pb}=\mathrm{Pb} 1000 \mathrm{~m} . \mathrm{e} \text {. } \\
\text { (Lapin ot al. 1987) }\end{array}$ & 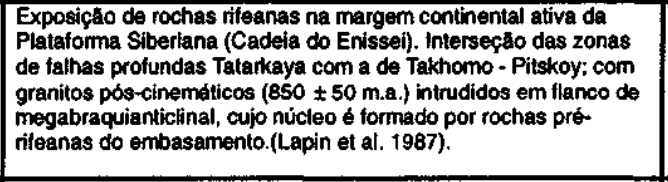 & $\begin{array}{c}6-8 \mathrm{Km} \\
530-570 \cdot \mathrm{C} \\
2,4-2,8 \mathrm{Kbar}\end{array}$ & $\begin{array}{l}\text { Magnésio-aftredsonita - flogopita } \\
\text { beforsitos com apatita e pirocloro. } \\
\text { Slyuditos no exocontalo. Antibólio- } \\
\text { teldspato fenitos apoxisticos; anfibólio- } \\
\text { flogopita-albita fenitos e antibólio- } \\
\text { carbonato metassomatitos apomár. } \\
\text { mores. }\end{array}$ \\
\hline 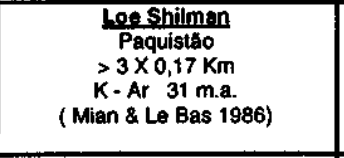 & 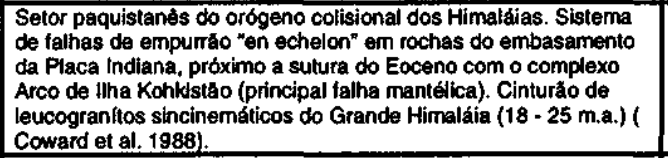 & $>5 \mathrm{Km}$ & $\begin{array}{l}\text { Blotita - magnésio-artvedsonita } \\
\text { carbonatitos com apatita. Egirina- } \\
\text { anfibólio- feldspalo fenitos com apatita } \\
\text { flogopita apoxistos no contato. }\end{array}$ \\
\hline $\begin{array}{c}\text { MududTank } \\
\text { Austrália } \\
>4.5 \times 0,5 \mathrm{~km} \\
\mathrm{Fb}-\text { Sr } 735 \pm 72 \mathrm{~m} . \mathrm{a} \text {. } \\
\text { U - Pb } 732 \pm 5 \mathrm{~m} . \mathrm{a} \text {. } \\
\text { (Crohn \& Moore 1984) }\end{array}$ & $\begin{array}{l}\text { Estrutura dobrada intraplatalormal Amadies da Platatoma } \\
\text { Australiane. Cinturáo frontal do nileano tardio (Orogenia Paterson) } \\
\text { de talhas invetsas em escamas no limite do Escudo de Aranta de } \\
\text { idade Ar. Zona transversal do lineamento de Woolonga (Currle et } \\
\text { al. 1992). }\end{array}$ & $>5 \mathrm{Km}$ & $\begin{array}{l}\text { Flogopita sovitos a beforsitos com apatita } \\
\text { e pirocloro. Syuditios e rochas calcitico } \\
\text { feldspáticas do exocontato. }\end{array}$ \\
\hline $\begin{array}{l}\frac{\text { Sillinilirvi }}{\text { Finlandia }} \\
14 \times 1,5 \mathrm{~km} \\
\mathrm{~K}-\mathrm{Ar} 1785-2030 \mathrm{ma} . \\
(\text { Puustinen } 1971)\end{array}$ & 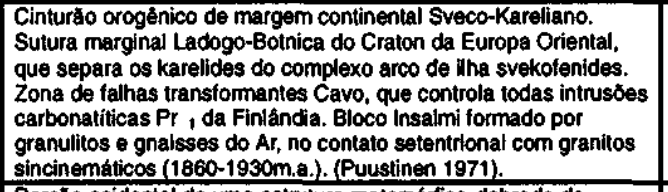 & $\begin{array}{c}4 \cdot 5 \mathrm{Km} \\
390 \cdot 520^{\circ} \mathrm{C} \\
1,5 \cdot 2,2 \mathrm{Kbar}\end{array}$ & $\begin{array}{l}\text { Richterita - tetrefereriflogopita sovitos com } \\
\text { apatita. Styuditos o rochas flogo-pitico- } \\
\text { leldspáticas no exocontato e anfibólio - } \\
\text { piroxenio - microclíneo fenitos } \\
\text { apognáissicos. }\end{array}$ \\
\hline $\begin{array}{c}\text { Cantley } \\
\text { Canadá } \\
22 \times 4 \text { Km } \\
\text { K- Ar } 580 \cdot 1050 \text { ma. } \\
\text { (Hogarth } \& \text { Lapoite } 1985 \text { e } \\
\text { Hogarth et al. 1985) }\end{array}$ & $\begin{array}{l}\text { Porça ocidental de uma estrutura metamórfica-dobrada da } \\
\text { Provincia Greenville do Escudo Canadense. Sistema de falhas de } \\
\text { empurrao om rochas supracrustais metassedimentares, intrudidas } \\
\text { por granitos sintectónicos (1065 } \quad \text { \$15 m.a.) ( Hanmer } 1988 \text { e } \\
\text { Charbonneau \& Hogarth 1988) }\end{array}$ & $\begin{array}{c}2 \cdot 3 \mathrm{Km} \\
260 \cdot 320 \times \mathrm{C} \\
0,7+0,9 \mathrm{Kbar}\end{array}$ & $\begin{array}{l}\text { Eğinina ratuhatos com calcita, barita e } \\
\text { monazita. Eginina albititos no exocontato. } \\
\text { Anfibólio - feldspalo fernitos apognáissicos. }\end{array}$ \\
\hline $\begin{array}{c}\frac{\text { Anqicodos Dins }}{\text { Brasil }} \\
2,1 \times 0.45 \mathrm{Km} \\
\text { U- Pb } 2011 \pm 6 \text { ma. } \\
\text { (Silva et al. } 1987 \text { e 1988) }\end{array}$ & $\begin{array}{l}\text { Embasamento ensiálico da Faixa Fiacho do Pontal situada no } \\
\text { bordo setentrional do Cráton do Săo Francisco. Zona de colisăo } \\
\text { de blocos crustais, tectónica dúctil tangencial com transporte de } \\
\text { SE para NW de idade Brasiliana. Zona de Falha inversa Santa } \\
\text { Úrsula-Serra do Mejo (Silva et al. 1988; Alkmin et al. 1993; Leite } \\
\text { \& Santos 1994). }\end{array}$ & & $\begin{array}{l}\text { Olivina-apatita sovito, biolita-apatita } \\
\text { sovitos e magnetita-olivina-apatita sovitos. } \\
\text { Albita sovitos no endocontato e albititos, } \\
\text { alcalteldspato sienito fenitos e quartzo- } \\
\text { albitita fenitos apograniticos e } \\
\text { apognálissicos no exocontato }\end{array}$ \\
\hline
\end{tabular}

De acordo com a terminologia atual, os fenitos são considerados como rochas metassomáticas da etapa magmática, que se formam pela ação das emanações provenien-tes dos magmas alcalinos e carbonatíticos sobre quaisquer rochas silicáticas encaixantes (Heinrich 1985; Kresten \& Morogan 1986). Os parâmetros de formação dos carbo-natitos, foram determinados utilizando o geotermobarômetro calcita-dolomita de Talantsev (1986). 
2 - os carbonatitos sintectônicos normalmente não estão vinculados com a série "tradicional" de diferenciados magmáticos encontrados nos complexos ultrabásico-alcalino-carbonatíticos do "Tipo Central", nem com qualquer outra manifestação de magmatismo alcalino. Em alguns complexos carbonatíticos lineares, verifica-se a associação de carbonatitos com rochas de composição sienítica (Angico dos Dias e alguns outros): ao que tudo indica ela é devida a processos de reomorfismo e metassomatose das rochas encaixantes alumossilicáticas pela ação do magma carbonatítico rico em álcalis; no entanto, na maioria das vezes a origem dos sienitos associados é atribuída ao intenso processo de fenitização das rochas encaixantes que alojam as rochas carbonatíticas. Por outro lado, os dados geológicos, em todos os casos, mostram que predomina o mecanismo de intrusão forçada dos carbonatitos durante a qual ocorre uma ação ativa (dinâmica, mecânica e química) do magma carbonatítico saturado de componentes voláteis sobre as rochas encaixantes. Consequentemente, desenvolve-se concomitantemente com o processo de metassomatismo alcalino, o hibridismo e a assimilação das encaixantes. No que se refere à composição, os carbonatitos sintectônicos podem ser denominados como complexos carbonatítico-feniticos ou complexos carbonatíticos com metassomatitos alcalinos.

3 - os complexos carbonatítico-feníticos situam-se em cinturões orogênicos atuais [Loe Shilman (Mian \& Le Bas 1986 e outros)], em cinturões do Neógeno e em seus análogos do Paleozóico e Pré-Cambriano (Sangu, Angico dos Dias, Chernigov, etc.). Eles, como regra, estão desconectados no espaço e no tempo com os Complexos Carbonatíticos do Tipo Central, os quais se intrudem predominantemente em ortoplataformas. Nos casos em que os complexos carbonatíticofeníticos se localizam nas partes internas das plataformas, apresentam idades muito antigas (Chernigov-2.000 m.a., Bagdasarov et al. 1982. Siilinjärvi- 2.260-2.530 m.a., Puustinen 1971; Dubrava-1.900-2.044 m.a., Bagdasarov et al. 1985; Angico dos Dias-2.010 m.a., Silva et al. 1988; Newania- 959 m.a., Viladkar \& Wimmernauer 1984).

4 - as idades desses complexos mostram que eles se formaram antes da estabilização protoplataformal e instalação do regime plataformal. $\mathrm{O}$ que torna os carbonatitos lineares singulares é a sua colocação na crosta terrestre durante a evolução de cinturões móveis, em ambiente que precede a compressão e o dobramento dos mesmos.

5 - a intrusão dos complexos carbonatítico-feníticos é controlada por zonas lineares de falhas de empurrão e falhas profundas de alto ângulo, bem como pelos cruzamentos formados por essas falhas com lineamentos transversais. A disposição dos carbonatitos sintectônicos está relacionada à combinação da tectônica tracional com a compressiva e nesta fase ocorre uma ligação estrutural e temporal dos carbonatitos com o magmatismo granitóide. Os carbonatitos se localizam em falhas regionais que secionam estruturas tectônicas de segunda ordem como flancos e ápices de anticlinais, bordas de domos granito-gnáissicos, exocontatos de intrusões graníticas. É digno de nota que os carbonatitos se dispõem de modo conforme em relação às camadas de rochas metamórficas em zonas e cinturões de cisalhamento de transtensão e zonas de fissuras paralelas ao trend geral do cinturão, e/ou ao longo da interface de acamamento ou foliação das rochas encaixantes.

6 - esse tipo de carbonatito não apresenta múltiplos estágios de diferenciação magmática, mas, ao se compararem os vários complexos carbonatíticos lineares formados à diferentes profundidades, verifica-

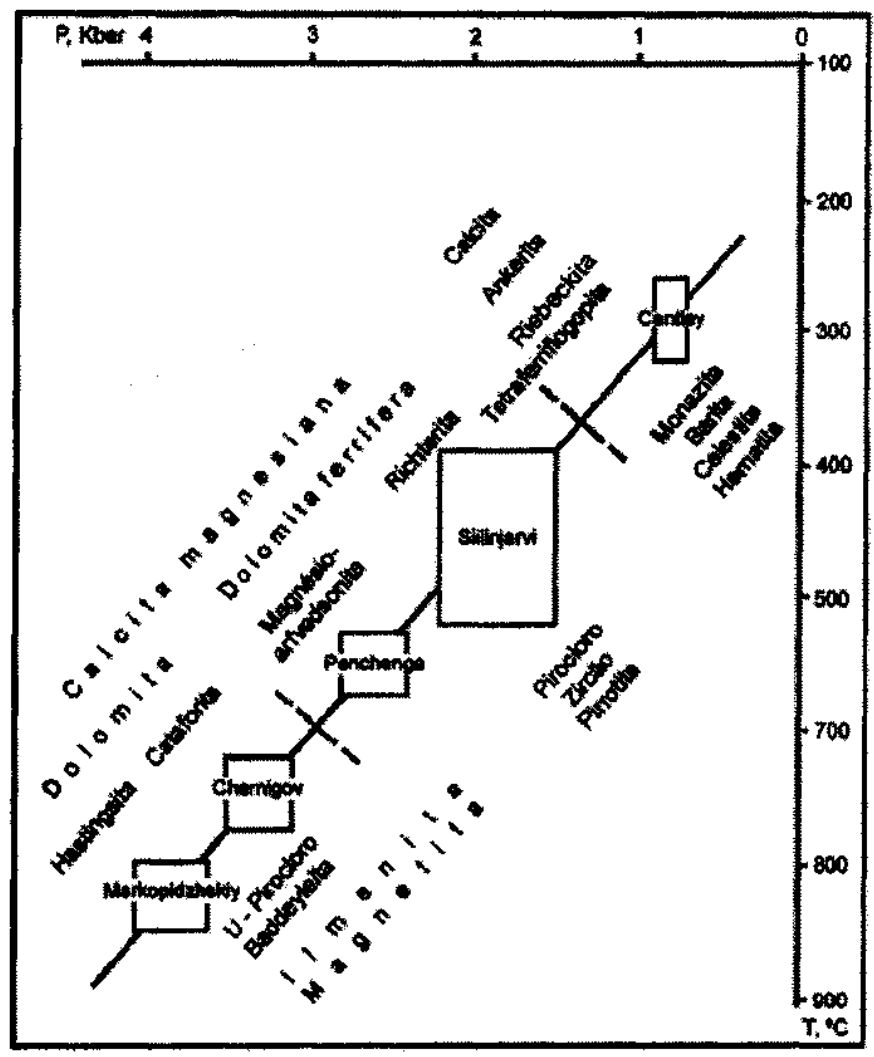

Figura 5 - Fácies de temperatura, pressão e composição mineralógica de carbonatitos lineares (Ploshko 1989).

Tabela 6 - Regime geológico-tectônico deformação dos carbonatitos e os seus tipos morfológico-formacionais (Lapin \& Ploshko 1988).

\begin{tabular}{|c|c|c|c|c|c|c|c|}
\hline $\begin{array}{l}\text { Tipas Morfológico- } \\
\text { Formacionais de } \\
\text { Complexos } \\
\text { Cantonatíticos }\end{array}$ & $\begin{array}{l}\text { Ambiente Geológico- } \\
\text { Tectónico de } \\
\text { Formaça e } \\
\text { Disposiça Espacial } \\
\text { dos Complexos } \\
\text { Crabonafíticos }\end{array}$ & $\begin{array}{c}\text { Relaçāo Geológica } \\
\text { Temporal dos } \\
\text { Complexos } \\
\text { Carbonatíticos com as } \\
\text { Rochas Encaixantes }\end{array}$ & $\begin{array}{l}\text { Profundidade de } \\
\text { Inunusão, Jdade } \\
\text { Absolula dos } \\
\text { Complexos } \\
\text { Cartonatíticos }\end{array}$ & $\begin{array}{c}\text { Caracteristicas } \\
\text { Energticis do } \\
\text { Regime de Fortivacăa } \\
\text { dos Complexos } \\
\text { Carbonalfticos }\end{array}$ & $\begin{array}{l}\text { Fomin e Dimensio } \\
\text { dos Complexas } \\
\text { Cartonatiticos }\end{array}$ & $\begin{array}{l}\text { Rochas Magnaficas e } \\
\text { Metassomáticas que } \\
\text { Acompanham os } \\
\text { Carbonatilos }\end{array}$ & $\begin{array}{l}\text { Grau de } \\
\text { Diferenciacto dos } \\
\text { Cartonalites }\end{array}$ \\
\hline $\begin{array}{l}\text { Zonas lineares de } \\
\text { carbonaltos e } \\
\text { metassomatitos } \\
\text { alcalimos }\end{array}$ & 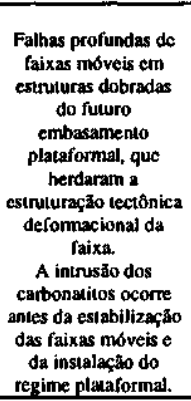 & $\begin{array}{l}\text { Os carbonstilos se } \\
\text { disprem de modo } \\
\text { concondante ou } \\
\text { subparalelo ds rochas } \\
\text { encaixantes. }\end{array}$ & $\begin{array}{c}\text { Prodominan } \\
\text { complexos de grande } \\
\text { c média } \\
\text { profundidade. Idades } \\
\text { antigas do } \\
\text { Paleoproterozoico } \\
\text { ( em sua majoria) }\end{array}$ & $\begin{array}{l}\text { Grande dissipacso de } \\
\text { cnergia ao longo da } \\
\text { zona da lalha } \\
\text { profunda, auséncia de } \\
\text { grandes anomalias } \\
\text { lérmicas locais nas } \\
\text { rochas encaixantes. } \\
\text { que tem por } \\
\text { característica alto } \\
\text { fluxo termico. }\end{array}$ & 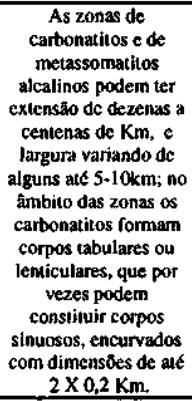 & 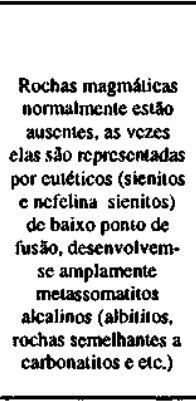 & 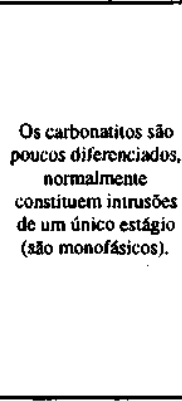 \\
\hline $\begin{array}{l}\text { Complex 0s } \\
\text { curbonatiticos do } \\
\text { "tipo central" }\end{array}$ & 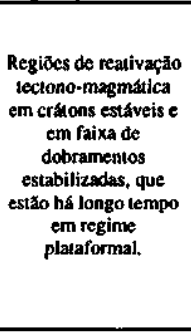 & $\begin{array}{l}\text { Os complexos } \\
\text { carbonatílicos } \\
\text { apresemtam contalos } \\
\text { discordantes em } \\
\text { relayato as rochas } \\
\text { encaixantes. O } \\
\text { diapirismo } \epsilon \text { umm } \\
\text { caracieristica do } \\
\text { magmatisno, } \\
\text { presença de estruturas } \\
\text { cupolfformes nas } \\
\text { eacaixantes. }\end{array}$ & $\begin{array}{c}\text { Predominantemente } \\
\text { complex os } \\
\text { superficiais, de baixa } \\
\text { profundidede e idade } \\
\text { variad }\end{array}$ & $\begin{array}{c}\text { Os complexos } \\
\text { carbonaufiticos cxihem } \\
\text { mitidamente cxcesso } \\
\text { de energia termal, } \\
\text { formam grandes } \\
\text { anomalitas térmicas } \\
\text { nas rochas } \\
\text { encaixantes, que } \\
\text { apresentam bajxo } \\
\text { fluxo termico. }\end{array}$ & 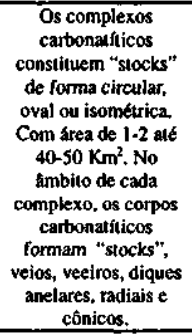 & 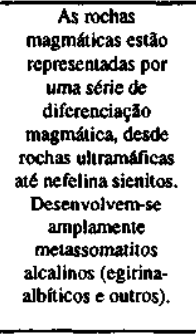 & 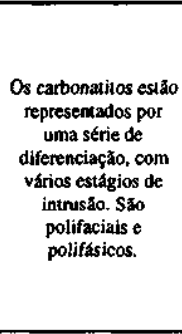 \\
\hline
\end{tabular}


se neles uma notória diferenciação vertical. Assim, com o aumento da profundidade de colocação dos complexos carbonatíticos, temos fácies de carbonatitos de temperatura e pressão cada vez mais altos, constios carbonatitos de mais alta temperatura e pressão (Complexo de Chernigov, $\mathrm{T}>600{ }^{\circ} \mathrm{C}$; $\mathrm{P}>3 \mathrm{kbar}$ ) são constituídos por dolomita carbonatitos, com ou sem olivina, flogopita, hastingsita, cataforita, magnetita, ilmenita e U-pirocloro, e se colocam a profundidades superiores a $10 \mathrm{~km}$. Os carbonatitos de média temperatura (Complexos de Tatarskaya e Siilinjärvi, $\mathrm{T}=400-600{ }^{\circ} \mathrm{C} ; \mathrm{P}=1,5-3 \mathrm{kbar}$ ) são constituídos por carbonatitos ferro-dolomíticos e calcíticos, tendo como minerais silicáticos máfícos das séries flogopita-tetraferriflogopita e magnésio-arvfedsonita-richterita e como acessório pirocloro, e se intrudem a profundidades de $5 \mathrm{a} 10 \mathrm{~km}$. Os carbonatitos de baixa temperatura e pressão (Cantley, $\mathrm{T}<400{ }^{\circ} \mathrm{C}$; $\mathrm{P}<1,5 \mathrm{kbar}$ ), são constituídos por ankerita, barita, calcita em associação paragenética com riebeckita, egirina, ilmenita, monazita, além desses minerais, contém fluorita e fluor-carbonatos de terras raras, e se alojam a profundidades situadas entre 2 e $5 \mathrm{~km}$ (Fig.5).

A diferenciação vertical do "sistema" carbonatítico se deve provavelmente ao equilíbrio da energia térmica do magma carbonatítico em relação às rochas encaixantes. Nessas condições, na presença de alto fluxo térmico e de um estável gradiente térmico nos cinturões móveis, temos, a cada profundidade, a formação de carbonatitos de uma determinada e específica fáceis de temperatura e pressão. Destarte, os carbonatitos sintectônicos caracterizam-se por apresentarem um tuídos por minerais formadores de rocha e de minério distintos. Assim,

estágio de intrusão e uma fácies petrográfica sem associação com rochas magmáticas alcalinas de altas temperaturas.

$\mathrm{O}$ regime tectônico e as principais características dos complexos carbonatítico-metassomáticos e dos complexos carbonatíticos do tipo central, estão relacionadas na Tabela 6.

CONSIDERAÇÕES FINAIS Concluindo, convém salientar que os complexos lineares carbonatítico-feníticos, encontrados e descritos nos últimos anos em número considerável, aumentam as perspectivas de descobertas de novas províncias e jazidas de fósforo e de elementos raros em faixas de dobramentos e no embasamento de regiões plataformais. Provavelmente, muitos dos complexos carbonatítico-feníticos acham-se recobertos por sedimentos plataformais jovens. Em função disso, cremos que eles sejam mais frequentes do que se supunha até agora.

O desenvolvimento de trabalhos sistemáticos de prospeção geológica, geofísica, geoquímica e pesquisa através de sondagens ao longo de falhas profundas em plataformas e cinturões móveis consolidados permitirá encontrar novas zonas lineares carbonatítico-feníticas, e possibilitará ampliar consideravelmente as reservas de terras raras céricas, nióbio, fosfatos e zircônio.

Agradecimentos Um dos autores (WI) agradece ao Conselho Nacional de Desenvolvimento Científico e Tecnológico - CNPq pela concessão da bolsa de Recém-Doutor, Processo: 300200-93-5 (NV) junto ao DEGEO-EM-UFOP, e aos Profs. Drs. Benjamin Bley de Brito Neves e Miguel Angelo Stipp Basei, e a dois revisores anónimos pelas críticas e sugestões que melhoraram este texto.

\section{Referências}

Alkmin F.F., Brito Neves B.B.do, Alves J.A.C. 1993. Arcabouco tectônico do Cráton do São Francisco. In: Dominguez J.M.L. \& MISI A. (eds.). 1993. O Cráton do S3o Francisco. Salvador, SBG Núcleo BA-SE, 45-62.

Bagdasarov Yu.A., Garanin V.K., Kudriavtseva G.P. 1982. Particularidades da composição dos minerais óxidos de ferro e titânio da Zona Carbonatítica de Chernigov (Priazov) e condições de sua formação. Geol. Rud. Mestorozhd., 3:37-48 (em russo).

Bagdarasov Yu.A., Voronovskiy S.N., Ovchinnikova L.N. 1985. Características geológicas e idade dos carbonatitos da Anomalia Magnética de Kursk._DoW. Akad. Nauk SSSR, 282(2):404-408 (em russo).

Baluev A.S. 1986 . Estruturas anelares e em arco no Bloco de Priazov do Escudo Ucraniano e a sua importância mineragenética. Geol. Zhurnal, 46(4):24-35 (em russo).

Bell K.(ed.) 1989. Carbonatites. Génesis and Evolution. London, Unwin Hyman. 618 p.

Bhatnagar K.P. 1991 .ELSEVIER'S Dictionary of Geociences. Russian- English. Amsterdam, Elsevier. $1023 \mathrm{p}$.

Brown P.E. 1964 .The Songwe Scarp Carbonatite and associated feldspathizalion in the Mbeya Range,Tanganyika. J. Geol. Soe. London, 120:223-240.

Borodin L.S. 1974. Principais Províncias e Séries de Rochas Alcalinas. Moscou, Nauka. 376 p.

Charbonneau B.W. \& Hogarth D.D. 1988. Geophysical expression of the carbonatites and fenites, east of Cantley, Quebec. Current Research, Part C, Geol. Sur. Can., Paper 88-1C, 259-269.

Coward M.P., Butler R.W., Chambers A.F. et al. 1988. Folding and imbrication of the Gudian crust during Himalayan collision. Phil Trans. R. Soe. London, A326(1589):89-1 16.

Crohn P.W. \& Moore P.H. 1984. The Mud Tank Carbonatite Strangways Range, central Austrália. J. Aust. Bur. Miner. Resour., Geol. Geophys., 9:13-18.

Currie K. 1976. Carbonatite complex lacking associated nephelinitic rocks. In: Currie K. 1976. The Alkaline Rocks of Canada. Buli. Can. Geol. Surv., 239:119-136.

Currie K., Knutson J., Temby P.A. 1992. The Mud Tank Carbonalite Complex, Central Austrália - An Example of Melasomatism al Mid-Crustal Leveis. Contrib. Mineral Petrol., 109(3):326-339.

Epstein E.M. 1994. Modelo Geológico-Petrológico e Características Genéticas dos Complexos Carbonatiticos Mineralizados. Moscou, Nauka, 256 p. (em russo).

Daly M.C. 1988. Crustal Shear Zones in Central África: A kinematic approach to proterozoic tectonics. Episodes, 11(1):5-11.

Glevasskiy E.B. 1989. Reconstrução paleogeodinâmica da parte sudeste do Escudo Ucraniano para o início do pré-cambriano. In: Tectonosfera da Ucrânia. Kiev, Naukova Dumka, 68-75 (em russo)

Glevasskiy E.B. \& Krivdik S.G. 1981. Complexo Carbonatítico Pré-Cambriano do Priazov. Kiev, Naukova Dumka, 227 p. (em russo)

Glevasskiy E.B. \& Krivdik S.G. 1985. Um cinturão de rochas ultrabásico-alcalinas no Priazov Ocidental. Geol Zhumal, 45(4):58-63 (em russo).

Hanmer S. 1988. Ductile thrusting at mid-crustal level, southwestern Grenville Province. Can. J. Earth Sei., 25(7): 1049-1059.

Heinrich E.Wm. 1985. Infinite variations on a fenite theme. J. Min. Soe. india, Sukhcswala Volume, 151-162

Hogarth D.D. \& Lapointe P. 1984. Amphibole and pyroxene developmenl in fenite from Cantley, Quebec. Can. Mineral, 22:281-295.

Hogarth D.D., Hartree R., Loop J. 1985. Rare-earth element minerais in four carbonatites near Gatineau, Quebec. Am. Mineral.70:1135-1142.

Kukharenko A.A., Bulakh A.G., Ilinskiy G.A., Shinkarev N.F., Orlova M.F. 1971. Complexo caledoniano de rochas ultrabásicas, alcalinas e carbonatitos da Península de Kola e norte da Karélia. Moscou, Nedra,768p. \{em russo).

Kapustin Yu.L., Lapitskiy E.M., Potrebnoy V.T., Storchak P.N., Kochanov E.N. 1977. Uma zona carbonatítica no Escudo Ucraniano. Sov. Geol. 9:80-92 (em russo).

Kogarko L.N., Kononova V.A., Orlova P., Woolley A .R. 1995. Alkaline Rocks and Carbonatites ofthe World. Part 2. Former USSR. London, Chapman \& Hall, $226 \mathrm{p}$.

Kresten P. \& Morogan V. 1986. Fenitization at the Fen Complex, southern Norway. Ltthos, 19:27-42.

Lapin A.V. \& Ploshko V.V. 1988. Tipos morfológico-formacionais e regimes geológico-tectônicos de formação de carbonatitos. Izv. Akad. Nauk. SSSR, Ser. Geol., 1:66-73 (em russo).
Lapin A.V., Ploshko V.V., Malishev A.A. 1987. Carbonatitos na Zona de Falha Profunda Tártara na Cadeia do Yenissei. Geol. Rud. Mestorozhd., 1:30-45 (em russo).

Lapin A.V. \& Tolstov A.V. 1995. Jazidas em Mantos de Intemperismo de Carbonatitos. Moscou, Nedra, 208 p. (em russo).

Leite C.M.M. \& Santos R.A. 1994. Tectônica e estrutura da região de Campo Alegre de Lourdes, NNW do Estado da Bahia. In: Congr. Brás. Geol., 38, Camboriú, 1994. Resumos Expandidos. Camboriú, SBG. 1:272-274.

Levin V.Ya., Roncnson B.M., Levina I.A. 1978. Carbonatitos da Província Alcalina de IlmenVishnovie Gory, nos Urais. Dokl. Akad. Nauk SSSR, 240(4):930-933 (em russo).

Mian I. \& Lê Bas M.J. 1986. Sodic amphiboles in fenites from the Loe Shilman Carbonatite Complex, NW Pakistan. Mineral. Mag., 50(356): 187-197.

Necheliustov G.N. \& Pozharitskaya L.K. 1986. Evolução da composição dos pirocloros em um dos complexos carbonatíticos da Plataforma Europeia Oriental. Mineral. Zhurnal, 8(5):38-48 (em russo).

Paffengolts K.N. (ed.). 1973. Dicionário Geológico T.2. Moscou, Nedra, 456 p. (em russo).

Pell J. \& Hoy T. 1989. Carbonatites in a Continental Margin Environment - The Canadian Cordillera. p.200-220. In: BELL K.(ed.) 1989. Carbonatites. Génesis and Evolution. London, Unwin Hyman. 618 p.

Ploshko.V.V. 1989. Critérios para prospecção e pesquisa de carbonatitos sincinemáticos em faixas de dobramentos. In: Bagdasarov Yu. A. \& Efimov A.F. (eds.). 1989. Prognose e Avaliação de Carbonatitos. Moscou, IMGRE, 56-73 (em russo).

Puustinen K. 1971. Geology ofthe Siilinjárvi Carbonatite Complex, Eastern Finland. Buli. Comm. Geol. Fin., 249:1-85.

Reddi A.G.B. \& Ramakrishna T. 1988. Subsurface struclure of the shield área of Rajasthan -Gujarat as inferred from gravity. In: Precambrian of the Aravalli Mountain, india. Bangalore, Geol. Soe. of índia. Memoir 7, 278-284.

Silva A.B., Liberal G.S., Issa Filho A., Rodrigues C.S., Riffel B.F. 1987. Depósito de fosfato em carbonatito pré-cambriano Angico dos Dias- BA. Soe. Brás. Geol., Núcleo da Bahia, Salvador, 15 p. (inédito)

Silva A.B., Liberal G.S., Grossi Sad J.H., Issa Filho A., Rodrigues C.S., Riffel B.F. 1988 Geologia e petrologia do Complexo Angico dos Dias (Bahia, Brasil). Uma associação carbonatítica pré-cambriana. Geochimica Brasiliensis, 2(1):81-108.

Sinha-Roy S. 1988. Proterozoic Wilson Cycles in Rajasthan. In: Precambrian ofthe Aravalli Mountain, Rajasthan, india. Bangalore, Geol. Soe. of índia. Memoir 7:95-107.

Struik L.C. 1988. Crustal evolution ofthe eastern Canadian cordillera. Tectonics, 7(4):727-747.

Talantsev A.S. 1981. Geotermobarometria com Base na Paragênese Dolomita - Calcita. Moscou, Nauka. 135 p. (em russo)

Tuttle O.F. \& Gittins J.(eds.).1966. Carbonatites. London and New York, Wiley Interscience, $591 \mathrm{p}$.

Varüainen H. \& Paarma H. 1980. Geological characteristics of the Sokli Carbonatite complex. Econ.Geol. 74:1296-1306.

Viladkar S.G. \& Wimmernauer W. 1984. Mineralogy and geochemistry of the Newania Carbonatite-Fenite Complex, Rajasthan, índia. Neues Jahrb. Mineral. Abh., 156(1): 1-21.

Vilkovich P.V. \& Pozharitskaya L.K. 1986. Compositional evolution of carbonatites in the Chernigov Zone, Azov Region. Geoch. Int. 27(2):92-100.

Verwoerd W.J. 1967. The Carbonatites of South Africa and West África. Handbook 6. Pretória, GeoLSurv. S. África, $452 \mathrm{p}$.

Woolley A.R. 1987. Alkaline Rocks and Carbonatites of World. Part 1: North America and South America .Austin, University of Texas Press, $222 \mathrm{p}$.

Woolley A.R. \& Kempe D.R.C. 1989. Carbonalites: nomenclature, average chemical compositions, and element distribution. In: Bell, K.(ed.) Carbonatites. Génesis and Evolution. London, Unwin Hynman, 1-14. 